\title{
Molecular Detection of Multidrug Resistant Staphylococcus aureus Isolated from Bovine Mastitis Milk in Bangladesh
}

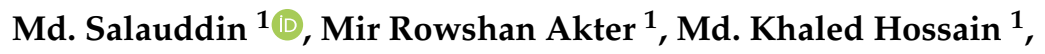 \\ K. H. M. Nazmul Hussain Nazir ${ }^{2, *(\mathbb{D})}$, Ayman Noreddin ${ }^{3,4}$ and Mohamed E. El Zowalaty ${ }^{3,5, * \text { (D) }}$ \\ 1 Department of Microbiology, Faculty of Veterinary and Animal Science, Hajee Mohammad Danesh Science \\ and Technology University, Dinajpur 5200, Bangladesh; salauddin.dvm@gmail.com (M.S.); \\ akter.rowshan@gmail.com (M.R.A.); khossainhstu@gmail.com (M.K.H.) \\ 2 Department of Microbiology and Hygiene, Faculty of Veterinary Science, Bangladesh Agricultural \\ University, Mymensingh 2202, Bangladesh \\ 3 Infectious Diseases and Anti-infective Therapy Research Group, College of Pharmacy and Sharjah Medical \\ Research Institute, University of Sharjah, Sharjah 27272, UAE; anoreddin@sharjah.ac.ae \\ 4 Department of Medicine, School of Medicine, University of California, Irvine, CA 92868, USA \\ 5 Zoonosis Science Center, Department of Medical Biochemistry and Microbiology, Uppsala University, \\ Uppsala SE 75185, Sweden \\ * Correspondence: nazir@bau.edu.bd (K.H.M.N.H.N.); elzow001@gmail.com (M.E.E.Z.)
}

Received: 19 February 2020; Accepted: 19 March 2020; Published: 30 March 2020

\begin{abstract}
The current study was conducted to isolate and identify multidrug-resistant Staphylococcus aureus (MDR-SA) from mastitis milk samples and to determine their antimicrobial susceptibility pattern. A total of 48 bovine mastitis (BM) milk samples were collected from different parts of the Rangpur division, Bangladesh. After the collection of milk samples, mastitis was confirmed using the California mastitis test. Isolation and identification of Staphylococcus aureus were performed using conventional cultural and biochemical tests as well as using molecular methods of PCR. Nucleotide sequence analysis of the $23 \mathrm{~S}$ rRNA gene of Staphylococcus aureus was determined. The antibiogram of the isolated bacteria was conducted using the disc diffusion method. Phylogenetic analysis of $23 S$ rRNA was done using MEGA 7, ClustalW multiple sequence alignment, and NCBI-BLAST tools, where the sequence of the isolate showed $98 \%$ to $99 \%$ identity. Antibiogram test using 15 antimicrobial agents showed that all of the Staphylococcus aureus isolates were classified as multidrug-resistant (MDR). It was found that the isolates were resistant to tetracycline, novobiocin, methicillin, vancomycin, and cephradine, and the isolates were sensitive to ciprofloxacin, azithromycin, norfloxacin, levofloxacin, gentamicin, and amoxicillin. The detection of MDR-SA in mastitis milk is alarming and represents a great public health concern. The findings of the present study help identify Staphylococcus aureus at the molecular level using $23 \mathrm{~S}$ rRNA gene sequencing and will help select the appropriate and effective antimicrobial agent to control BM in the northern part of Bangladesh.
\end{abstract}

Keywords: Bovine mastitis; Staphylococcus aureus; $23 \mathrm{~S}$ rRNA gene; multidrug resistance; zoonotic; methicillin-resistant; livestock; antimicrobial

\section{Introduction}

Bovine mastitis (BM) is an extremely common and genuine risk to the dairy industry throughout the world. BM is difficult to control due to the multifactorial nature of the disease, of which Staphylococcus spp. is notoriously involved [1]. Staphylococcus aureus (S. aureus) is a potential pathogen that is responsible for intramammary infections and decreases the health status of cows, leading to 
huge economic losses [2]. It is the leading pathogen that frequently appears in BM, however, its identification is comparatively costly [3]. Yearly costs related to the treatment of mastitis dairy livestock are more than one million dollars in the USA [4-6]. Antibiotics are indiscriminately used to control $\mathrm{BM}$. Antibiotic therapy is one of the most common practices for controlling BM, and antimicrobial drugs like chloramphenicol, ciprofloxacin, novobiocin, vancomycin, and tetracycline were reported to have poor effectiveness against $S$. aureus [7-10]. Several antibiotics have been used for BM treatment, however, nowadays, treatment failure is commonly reported [11]. The deliberate use of antimicrobial agents in veterinary practice is a major factor for spreading antibiotic-resistant bacterial pathogens to human populations, thus may potentially lead to public health issues $[5,11]$. Methicillin-resistant Staphylococcus aureus (MRSA) has been reported as a threat to both humans and animals [12-14]. Multidrug-resistant (MDR) S. aureus infections have been associated with high morbidly and economic losses. S. aureus is often found in dairy cow's milk and has been clinically proven to be a cause of mastitis [15]. It has been reported that humans sometimes consume raw milk [16]. Nowadays, livestock-associated and community-associated MRSA have been reported and are of great public health concern [17-20]. The consumption of contaminated milk and milk products was reported to be a source of infections by S. aureus [21]. S. aureus infections in humans may lead to septicemia, pneumonia, and dermatitis [22]. There has been limited research about the detection of S. aureus in Bangladesh [23-25]. In recent years, the prevalence of BM in the Rangpur division has been reported to be gradually increasing. In the present study, $23 S$ rRNA gene analysis was used to identify in-depth gene-specific $S$. aureus in the Rangpur division from BM milk. In addition, the study was conducted to determine the antimicrobial resistance pattern of $S$. aureus and the phylogenetic relatedness of the isolated S. aureus from BM, which may help control the imprudent use of antibiotics in veterinary practices for the treatment of $\mathrm{BM}$ and to increase public awareness.

\section{Materials and Methods}

\subsection{Ethics Statement}

The experimental procedures and protocols used in this study were approved by the Animal Ethics and Welfare Committee of the Institute of Research and Training, Hajee Mohammad Danesh Science and Technology University (approval number HSTU/RIT/2556).

\subsection{Sample Collection and Processing}

A total of 48 milk samples (10 mL) from cattle (Bos indicus) suffering from mastitis were collected from nine selected dairy farms of the Rangpur division of Bangladesh in September 2017 to January 2018 (Table 1). To confirm the mastitis in the cattle, the California Mastitis Test (CMT) was performed by mixing milk sample (3 $\mathrm{mL}$ from each quarter) and commercial CMT reagent $(3 \mathrm{~mL})$ using a partitioned plastic paddle, as previously described [26]. After screening the presence of mastitis by CMT tests, all milk samples were transferred to the Microbiology Laboratory, Department of Microbiology, Hajee Mohammad Danesh Science and Technology University (HSTU), for further microbiological processing. 
Table 1. Sample collection and frequency of bacterial isolates in the milk samples.

\begin{tabular}{cccccc}
\hline Samples Collection Area & $\begin{array}{c}\text { Number of } \\
\text { Samples }\end{array}$ & $\begin{array}{c}\text { Samples } \\
\text { Positive for } \\
\text { E. coli (\%) }\end{array}$ & $\begin{array}{c}\text { Samples } \\
\text { Positive for } \\
\text { Staphylococcus } \\
\text { spp. (\%) }\end{array}$ & $\begin{array}{c}\text { Samples } \\
\text { Positive for } \\
\text { Streptococcus } \\
\text { spp. (\%) }\end{array}$ & $\begin{array}{c}\text { Samples } \\
\text { Positive for } \\
\text { Klebsiella spp. } \\
\text { (\%) }\end{array}$ \\
\hline Chirir bandar & 12 & 100 & 100 & 58.34 & 50 \\
Sadar Livestock office Dinajpur & 8 & 100 & 100 & 62.5 & 62.5 \\
Nandigram, Birganj & 5 & 100 & 100 & 60 & 60 \\
Birol, Dinajpur & 10 & 100 & 100 & 70 & 60 \\
Sadullahpur, Gaibandha & 2 & 100 & 100 & 100 & 50 \\
Kornai, Baserhat & 2 & 100 & 100 & - & 100 \\
Thakurgaon, Sadar & 2 & 100 & 100 & 100 & 50 \\
Thakurgaon, Haripur road & 4 & 100 & 100 & 50 & 75 \\
Birganj Livestock office & 3 & 100 & 100 & 66.67 & 100 \\
Total & 48 & 48 & 48 & 28 & 30 \\
\hline
\end{tabular}

\subsection{Isolation and Identification of Staphylococcus spp.}

All positive samples (confirmed by clinical signs and CMT test) were cultured on Nutrient Agar (HI-MEDIA ${ }^{\circledR}$, Mumbai, India), Mannitol Salt Agar (MSA) (HI-MEDIA ${ }^{\circledR}$, Mumbai, India) and Staphylococcus Agar No. 110 (SAN 110) (HI-MEDIA ${ }^{\circledR}$, Mumbai, India) to observe colony morphology and staining characteristics, as described previously [27]. Samples were also cultured on blood agar medium (Merck, Darmstadt, Germany) enriched with defibrinated ox blood to determine the hemolytic activity of the isolates. The isolates were identified using conventional biochemical tests, as described previously [27-29].

\subsection{Antimicrobial Susceptibility Study}

The isolates were tested for their antibiogram using the disc diffusion method [30] using 15 antibacterial discs (HI-MEDIA ${ }^{\circledR}$, Mumbai, India). The isolates were cultured on Muller Hinton Agar (HI-MEDIA ${ }^{\circledR}$, Mumbai, India) according to the guidelines of the National Committee for Clinical Laboratory Standards [31]. The antibiotic discs used in the current study were gentamicin (GEN-10 $\mu \mathrm{g})$, amoxicillin (AMX-30 $\mu \mathrm{g}$ ), chloramphenicol (C-30 $\mu \mathrm{g}$ ), ciprofloxacin (CIP-5 $\mu \mathrm{g})$, bacitracin (B-10 $\mu \mathrm{g})$, azithromycin (AZM-30 $\mu \mathrm{g}$ ), erythromycin (E-15 $\mu \mathrm{g})$, methicillin (MET-5 $\mu \mathrm{g})$, novobiocin (NV-30 $\mu \mathrm{g})$, vancomycin (VA-30 $\mu \mathrm{g})$, norfloxacin (NX-10 $\mu \mathrm{g}$ ), tetracycline (TE-30 $\mu \mathrm{g})$, levofloxacin (LE-5 $\mu \mathrm{g}$ ), nalidixic acid (NA-30 $\mu \mathrm{g})$, and cephradine $(\mathrm{CH}-30 \mu \mathrm{g})$. The zone of inhibition was recorded in millimeters and results were interpreted as previously described [32].

\subsection{DNA Extraction}

A single pure colony of S. aureus strain BARC001 culture from SAN 110 was cultured overnight in Luria Bertani broth (HI-MEDIA ${ }^{\circledR}$, Mumbai, India) at $37^{\circ} \mathrm{C}$. Genomic DNA of Staphylococcus aureus (n $=48$ ) was extracted using a Wizard ${ }^{\circledR}$ Genomic DNA Purification Kit (Promega Corporation, Madison, WI, USA) according to the manufacturer's protocol. Extracted DNA was quantified at $260 / 280 \mathrm{~nm}$ by Nanodrop (Thermo Fisher Scientific, Dreieich, Germany) and stored at $-20{ }^{\circ} \mathrm{C}$.

\subsection{PCR Amplifications}

Reference primers (Integrated DNA Technologies (IDT), Coralville, IA, San Diego, USA) Sau 234 (F) (5' CGATTCCCTTAGTAGCGGCG 3') and Sau 1501 (R) (5' CCAATCGCACGCTTCGCCTA $3^{\prime}$ ) targeting the $23 S$ rRNA gene (Gene bank database S. aureus, GI no. 288516) were used to amplify the 23 rRNA gene, as previously described [33]. The primers (20 pico-moles) used in this study generated an amplicon of $1267 \mathrm{bp}$ as visualized by gel electrophoresis (MGU-402T, CBS Scientific, United Kingdom). The PCR reaction volume was $25 \mu \mathrm{L}$ and consisted of $12.5 \mu \mathrm{L} 2 \mathrm{x}$ PCR master mix (Promega Corporation, Madison, WI, USA), $1 \mu \mathrm{L}$ forward primer, $1 \mu \mathrm{L}$ reverse primer, $8.5 \mu \mathrm{L}$ nuclease-free water, and $2 \mu \mathrm{L}$ DNA templet in each PCR tube. The PCR reaction was conducted using 
a thermocycler (Gene Atlas, Astec, Minamizato, Shime, Kasuya, Japan) with modifications from a previously described method [33]. The PCR reaction conditions were as follows: initial denaturation at $94{ }^{\circ} \mathrm{C}, 1$ cycle for $2 \mathrm{~min}$; denaturation at $94{ }^{\circ} \mathrm{C}$ for $45 \mathrm{~s}$; annealing at $58^{\circ} \mathrm{C}, 60.5^{\circ} \mathrm{C}, 60.9{ }^{\circ} \mathrm{C}, 61.3^{\circ} \mathrm{C}$ (gradient) for $60 \mathrm{~s}$; extension at $72{ }^{\circ} \mathrm{C}$ for $2 \mathrm{~min}$ for 35 cycles; and a final extension at $72{ }^{\circ} \mathrm{C}$ for $10 \mathrm{~min}$. The amplicons were visualized using $2 \%$ agarose gel (Promega Corporation, Madison, WI, USA).

\subsection{Sequencing and Phylogenetic Analysis}

The nucleotide sequence of the 23S rRNA gene was obtained by Sanger sequencing method using the ABI 3130 Genetic Analyzer (Applied Biosystems ${ }^{\circledR}$, Thermo fisher scientific, Waltham, MA, USA) and sequence data were submitted to NCBI nucleotide sequence database for analysis using the BLAST tool, the ClustalW multiple sequence alignment, and neighbor-joining method [34]. The phylogenetic tree was constructed using MEGA software [35]. The evolutionary distances were computed using the maximum composite likelihood method [36].

\section{Results}

\subsection{Isolation and Identification of MDR-SA}

A total of 48 clinical mastitis milk samples were collected from dairy cow farms from different areas of the Rangpur division (Table 1). Based on cultural examinations, four bacterial species, including Staphylococcus spp. (100\%, $n=48 / 48)$, Escherichia coli $(100 \%, n=48 / 48)$, and Klebsiella spp., (62.5\%, $n=30 / 48)$, and Streptococcus spp. $(58.3 \%, \mathrm{n}=28 / 48)$ were identified (Table 1$)$. It was found that S. aureus was isolated from all mastitis milk samples obtained from dairy cows. S. aureus showed gray-white colonies on SAN 110 and golden yellowish colonies on MSA plates. Isolates showed complete $(\beta)$ hemolysis on ox blood agar. The isolates were confirmed as S. aureus using different conventional biochemical tests.

The genomic DNA was used to confirm identity using the 23S rRNA and species-specific PCR. Isolates showed a band at $1267 \mathrm{bp}$ (Figure 1). PCR products (10 pico-moles) were submitted to the National Institute of Biotechnology (NIB), Savar, Dhaka, Bangladesh for partial length sequencing of the $23 \mathrm{~S}$ rRNA gene in both directions.

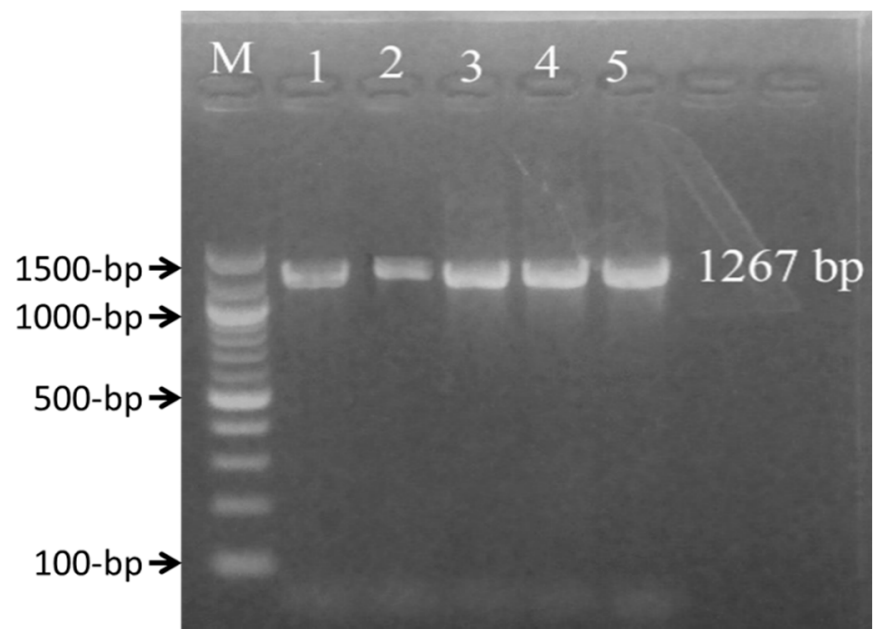

Figure 1. PCR amplification of 23S rRNA gene using the primers Sau 234 (F) and Sau 1501 (R) showing an amplicon size of 1267 bp. M: Marker 100 bp Plus DNA ladder.

BLAST analysis revealed 98\% homology with NCBI GenBank data set. Phylogenetic analysis was done by ClustalW multiple sequence alignment and the neighbor-joining method (Figure 2). 


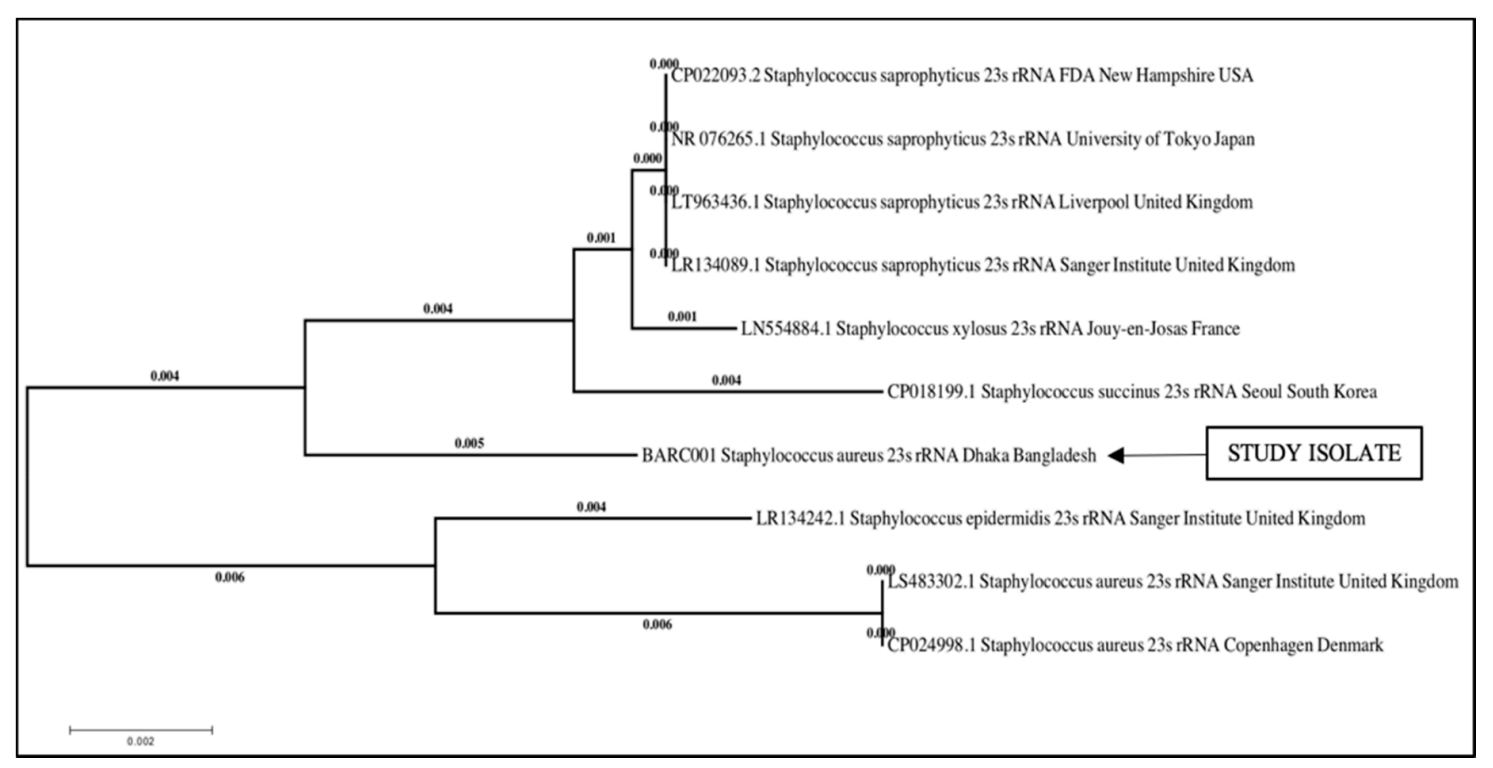

Figure 2. Phylogenetic tree of Staphylococcus aureus strain BARC001 $23 \mathrm{~S}$ rRNA gene sequence in the present study and related GenBank sequences.

The sequence analyses revealed that the $S$. aureus $(n=1)$ Strain BARS001 was closely related to isolates previously reported from South Korea, France, the United Kingdom, and the USA.

\subsection{Antibiogram of S. aureus Isolates}

The results of the antibiogram test of $S$. aureus isolated from mastitis milk samples against 15 antimicrobial agents revealed that all isolates tested were resistant to methicillin (MET-5 $\mu \mathrm{g}$ ), novobiocin $(\mathrm{NV}-30 \mu \mathrm{g})$, vancomycin (VA-30 $\mu \mathrm{g}$ ), tetracycline (TE-30 $\mu \mathrm{g}$ ), and cephradine (CH-30 $\mu \mathrm{g})$. On the other hand, isolates showed intermediate resistance to chloramphenicol (C-30 $\mu \mathrm{g})$, bacitracin (B-10 $\mu \mathrm{g})$, erythromycin $(\mathrm{E}-15 \mu \mathrm{g})$, and nalidixic acid (NA-30 $\mu \mathrm{g})$. The tested isolates were sensitive to six out of the 15 tested antimicrobial agents as shown in Table 2. 
Table 2. Antibiogram study of Staphylococcus aureus isolates in the current study.

\begin{tabular}{|c|c|c|c|c|c|c|c|c|c|c|c|c|c|c|c|c|}
\hline \multirow[b]{2}{*}{$\begin{array}{l}\text { Isolates } \\
(n=48)\end{array}$} & \multirow[b]{2}{*}{$\begin{array}{l}\text { Diameter of Zone } \\
\text { of Inhibition (mm) }\end{array}$} & \multicolumn{15}{|c|}{ Antibacterial Agents ( $\mu \mathrm{g} /$ disc) } \\
\hline & & $\begin{array}{c}\text { AMX } \\
(30)\end{array}$ & $\begin{array}{c}C \\
(30)\end{array}$ & $\begin{array}{l}\text { NX } \\
\text { (10) }\end{array}$ & $\begin{array}{c}\text { TE } \\
(30)\end{array}$ & $\begin{array}{l}\text { GEN } \\
(10)\end{array}$ & $\begin{array}{c}\text { B } \\
(10)\end{array}$ & $\begin{array}{c}\text { AZM } \\
(30)\end{array}$ & $\begin{array}{c}E \\
(15)\end{array}$ & $\begin{array}{l}\text { NV } \\
(30)\end{array}$ & $\begin{array}{c}\text { MET } \\
\text { (5) }\end{array}$ & $\begin{array}{l}\text { VA } \\
(\mathbf{3 0})\end{array}$ & $\begin{array}{l}\text { LE } \\
\text { (5) }\end{array}$ & $\begin{array}{l}\text { CIP } \\
\text { (5) }\end{array}$ & $\begin{array}{l}\mathrm{CH} \\
(25)\end{array}$ & $\begin{array}{l}\text { NA } \\
\text { (30) }\end{array}$ \\
\hline \multirow{3}{*}{$\begin{array}{c}\text { Staphylococcus } \\
\text { aureus }\end{array}$} & $\mathrm{S}$ & $15 \mathrm{~mm}$ & & $\begin{array}{c}19 \\
\mathrm{~mm}\end{array}$ & & $21 \mathrm{~mm}$ & & $\begin{array}{c}23 \\
\mathrm{~mm}\end{array}$ & & & & & $\begin{array}{c}26 \\
\mathrm{~mm}\end{array}$ & $\begin{array}{c}29 \\
\mathrm{~mm}\end{array}$ & & \\
\hline & I & & $\begin{array}{c}20 \\
\mathrm{~mm}\end{array}$ & & & & $\begin{array}{c}11 \\
\mathrm{~mm}\end{array}$ & & $\begin{array}{c}17 \\
\mathrm{~mm}\end{array}$ & & & & & & & $\begin{array}{c}24 \\
\mathrm{~mm}\end{array}$ \\
\hline & $\mathrm{R}$ & & & & 0 & & & & & 0 & 0 & 0 & & & 0 & \\
\hline
\end{tabular}

GEN: gentamicin; AMX: amoxicillin; C: chloramphenicol; CIP: ciprofloxacin; AZM: azithromycin; E: erythromycin; VA: vancomycin; NX: norfloxacin; TE: tetracycline; B: bacitracin; NV: novobiocin; MET: methicillin; LE: levofloxacin; CH: cephradine; NA: nalidixic acid; 0: no zone of inhibition; S: sensitive; I: intermediate; R: resistant. 


\section{Discussion}

Bovine mastitis (BM) is an inflammatory disease of dairy cows caused by various opportunistic bacteria that reduce milk yield and deteriorate the quality of milk composition $[37,38]$. BM is a threat to dairy farms and farmers [39]. The findings of the current study showed that the prevalence of S. aureus in mastitis milk samples was $100 \%(n=48)$. Cultural, biochemical, as well as molecular tests using the $23 S$ rRNA gene amplification were used to identify $S$. aureus.

The presence of $S$. aureus in milk in the present study was found to be higher than previous studies [16,40-44]. The high prevalence rate of $S$. aureus in the present study may be explained by differences in geographical distribution, immunological status, as well as biosecurity practices of the study areas in comparison to other studies. The antibiogram showed that all the isolates were classified as MDR, similar to a previous study [45]. In the current study, levofloxacin (26 mm) and ciprofloxacin $(29 \mathrm{~mm}$ ) demonstrated the highest antibacterial activity based on the zones of inhibition, which may be recommended for use to treat BM in the Rangpur division of Bangladesh. Nevertheless, a study by Jahan [16] revealed that more than $83.33 \%$ S. aureus from raw milk were susceptible to ciprofloxacin. The results of the antibiogram from the current study were similar to those previously reported [16,46,47]. All isolates in the present study were classified as multidrug-resistant (MDR) [48]. The 23S rRNA sequencing was a powerful tool for the identification of Staphylococcus aureus isolated from bovine mastitis and its evolutionary features. In this study, 23S rRNA gene sequencing was used to identify coagulase-positive (CoPS) S. aureus isolates of BM at the species level. The detection of MDR-SA is alarming for human health, as it has zoonotic potential. Livestock may play an important role in transmitting the bacteria to humans through milk $[49,50]$, which may represent a great threat to public health, farm-associated workers, and veterinarians. In recent years, the incidence of $S$. aureus has been increasing, and health care-associated MRSA and livestock-associated MRSA have commonly been reported, which has a major impact on public health [51,52]. The phylogenetic analysis showed that the MDR-SA isolate is closely related to those previously reported from other countries and regions $[9,16,17]$.

\section{Conclusions}

Livestock associated CoPS -SA, which is MDR, is notorious for its appearance in the Rangpur division, causing BM. Current research suggests that it is essential to stop the deliberate use of antibiotics to prevent MDR-SA. Proper hygienic practices and the maintenance of biosecurity measures are two of the most important steps to reduce infections. The findings of the present study help determine the evolutionary feature of $S$. aureus in the Rangpur division, and the antibiogram results help select the appropriate antimicrobial agents for the treatment of infected animals. The isolated S. aureus may be used for the future development of a mastitis vaccine using local isolates as a prophylactic measure in livestock.

Data Availability: The 23S rRNA sequence of Stapylococcus aureus strain BARC001 has been deposited at the National Center for Biotechnology Information (NCBI), U.S. National Library of Medicine (NLM) (Bethesda MD, USA) under the BioProject number PRJNA613919 (https://www.ncbi.nlm.nih.gov/bioproject/?term=PRJNA613919) (BioSample accession number SAMN14421930 (https://www.ncbi.nlm.nih.gov/biosample/?term=SAMN14421930) and GenBank accession number MT232660 (https://www.ncbi.nlm.nih.gov/nuccore/MT232660)).

Author Contributions: M.K.H. and M.R.A. conceptualized the study. M.S. designed and analyzed data. M.S. also wrote the initial draft manuscript and performed all experiments. M.K.H., K.H.M.N.H.N., A.N. and M.E.E.Z. contributed to writing, critical revisions and analysis of the data. M.E.E.Z. submitted the sequence to NCBI. All of the authors read and agreed the final version of the manuscript.

Funding: The Bangladesh Agricultural Research Council (BARC) and National Science and Technology (NST).

Acknowledgments: The authors would like to thank the Department of Microbiology, Hajee Mohammad Danesh Science \& Technology University and National Institute of Biotechnology (NIB), Bangladesh, for supporting this research. The authors are also thankful to the Bangladesh Agricultural Research Council (BARC) and National Science and Technology (NST) program forfinancial support.

Conflicts of Interest: The authors declare no conflict of interest. 


\section{References}

1. Forsman, P.; TiIsala, T.A.; Alatossava, T. Identification of Staphylococcal and Streptococcal causes of bovine mastitis using 16s-23s rRNA spacer regions. Microbiology 1997, 143, 3491-3500. [CrossRef] [PubMed]

2. Wang, D.; Zhang, L.; Zhou, X.; He, Y.; Yong, C.; Shen, M.; Szenci, O.; Han, B. Antimicrobial susceptibility, virulence genes, and randomly amplified polymorphic DNA analysis of Staphylococcus aureus recovered from bovine mastitis in Ningxia, China. China. J. Dairy Sci. 2016, 99, 9560-9569. [CrossRef]

3. Lange, C.C.; Brito Maria, A.V.P.; Reis Daniele, R.L.; Machado, M.A.; Guimaraes, A.S.; Azevedo Ana, L.S.; Salles, E.B.; Alvim Mariana, C.T.; Silva, F.S.; Meurer Igor, R. Species-level identification of staphylococci isolated from bovine mastitis in Brazil using partial 16S rRNA sequencing. Vet Microbiol. 2015, 176, 382-388. [CrossRef] [PubMed]

4. Hogan, J.S.; Berry, E.; Hillerton, E. Current Concepts of Bovine Mastitis, 5th ed.; National Mastitis Council: Verona, WI, USA, 2011.

5. Anderson, K.; Azizoglu, R. Detection and Causes of Bovine Mastitis with Emphasis on Staphylococcus aureus. Encycl. Agric. Food Syst. 2014, 2, 435-440.

6. Kuang, Y.; Tani, K.; Synnott, A.J.; Ohshima, K.; Higuchi, H.; Nagahata, H.; Tanji, Y. Characterization of bacterial population of raw milk from bovine mastitis by culture-independent PCR-DGGE method. Biochem. Eng. J. 2009, 45, 76-81. [CrossRef]

7. Saei, H.D. coa types and antimicrobial resistance profile of Staphylococcus aureus isolates from cases of bovine mastitis. Comp. Haematol. Int. 2010, 21, 301-307. [CrossRef]

8. Deb, R.; Kumar, A.; Chakrabort, S.; Verma, A.; Tiwari, R.; Dhama, K.; Singh, U.; Kumar, S. Trends in Diagnosis and Control of Bovine Mastitis: A Review. Pak. J. Boil. Sci. 2013, 16, 1653-1661. [CrossRef]

9. Xu, J.; Tan, X.; Zhang, X.; Xia, X.; Sun, H. The diversities of staphylococcal species, virulence and antibiotic resistance genes in the subclinical mastitis milk from a single Chinese cow herd. Microb. Pathog. 2015, 88, 29-38. [CrossRef]

10. Gomes, F.; Henriques, M. Control of Bovine Mastitis: Old and Recent Therapeutic Approaches. Curr. Microbiol. 2015, 72, 377-382. [CrossRef]

11. Tark, D.-S.; Moon, D.C.; Kang, H.Y.; Kim, S.-R.; Nam, H.-M.; Lee, H.-S.; Jung, S.-C.; Lim, S.-K. Antimicrobial susceptibility and characterization of extended-spectrum $\beta$-lactamases in Escherichia coli isolated from bovine mastitic milk in South Korea from 2012 to 2015. J. Dairy Sci. 2017, 100, 3463-3469. [CrossRef]

12. Declercq, P.; Petre, D.; Gordts, B.; Voss, A. Complicated community acquired soft tissue infection by MRSA from porcine origin. Infection 2008, 36, 590-592. [CrossRef] [PubMed]

13. Lewis, H.C.; Mølbak, K.; Reese, C.; Aarestrup, F.M.; Selchau, M.; Sørum, M.; Skov, R.L. Pigs as Source of Methicillin-Resistant Staphylococcus aureus CC398 Infections in Humans, Denmark. Emerg. Infect. Dis. 2008, 14, 1383-1389. [CrossRef] [PubMed]

14. Witte, W.; Strommenger, B.; Stanek, C.; Cuny, C. Methicillin-resistant Staphylococcus aureus ST398 in Humans and Animals, Central Europe. Emerg. Infect. Dis. 2007, 13, 255-258. [CrossRef] [PubMed]

15. Adesiyun, A.A.; Webb, L.A.; Romain, H.T. Prevalence and Characteristics of Staphylococcus aureus Strains Isolated from Bulk and Composite Milk and Cattle Handlers. J. Food Prot. 1998, 61, 629-632. [CrossRef]

16. Jahan, M.; Rahman, M.; Parvej, M.S.; Chowdhury, S.M.Z.H.; Haque, M.E.; Talukder, M.A.K.; Ahmed, S. Isolation and characterization of Staphylococcus aureus from raw cow milk in Bangladesh. J. Adv. Vet.- Anim. Res. 2015, 2, 49. [CrossRef]

17. Kwon, N.H.; Park, K.T.; Moon, J.S.; Jung, W.K.; Kim, S.H.; Kim, J.M.; Hong, S.K.; Koo, H.C.; Joo, Y.S.; Park, Y.H. Staphylococcal cassette chromosome mec (SCCmec) characterization and molecular analysis for methicillin-resistant Staphylococcus aureus and novel SCCmec subtype IVg isolated from bovine milk in Korea. J. Antimicrob. Chemother. 2005, 56, 624-632. [CrossRef] [PubMed]

18. Kamal, R.M.; Bayoumi, M.; El Aal, S.F.A. MRSA detection in raw milk, some dairy products and hands of dairy workers in Egypt, a mini-survey. Food Control. 2013, 33, 49-53. [CrossRef]

19. Song, M.; Bai, Y.; Xu, J.; Carter, M.Q.; Shi, C.; Shi, X. Genetic diversity and virulence potential of Staphylococcus aureus isolates from raw and processed food commodities in Shanghai. Int. J. Food Microbiol. 2015, 195, 1-8. [CrossRef] 
20. Monte, D.F.; Júnior, W.D.L.; Abley, M.; Gebreyes, W.A.; Oliveira, C. Antimicrobial resistance and genotypic relatedness of environmental Staphylococci in semi-extensive dairy farms. Vet. Anim. Sci. 2018, 6, 103-106. [CrossRef]

21. Zecconi, A.; Piccinini, R. Staph aureus: A problem for Italian dairy herds. Bull. Int. Dairy Fed. 1998, 330, $25-26$.

22. Lowy, F.D.; Zinkawa, K.; Omoe, S.; Aasbakk, K.; Macland, A. Staphylococcus aureus infection. N. Engl. J. Med. 1998, 339, 520-532. [CrossRef] [PubMed]

23. Manu, M.M.R. Prevalence, Risk Factors, and Antimicrobial Activity of Alovera gel Against the Bacterial Pathogens of Mastitis in Dairy Cows at Dinajpur District of Bangladesh. Master's Thesis, Hajee Mohammad Danesh Science and Technology University (HSTU), Dinajpur, Bangladesh, 2018.

24. Mia, M.T. Detection of Bacterial spp. from Clinical Mastitis in Dairy Cows at Nilphamari District and Their Antibiogram Study. Master's Thesis, Hajee Mohammad Danesh Science and Technology University (HSTU), Dinajpur, Bangladesh, 2016.

25. Maniruzzaman, M.; Khan, M.F.R.; Amin, M.M.; Paul, A.K.; Islam, M. Isolation and Identification of Bacterial Flora from Milk of Apparently Healthy Buffalo-Cows. Int. J. BioRes. 2010, 1, 13-16.

26. Schalm, O.W.; Noorlander, D.O. Experimental and observation leading to development of California mastitis test. J. Am. Vet. Med. Assoc. 1957, 130, 199-204. [PubMed]

27. Merchant, I.A.; Packer, R.A. Veterinary Bacteriology and Virology, 7th ed.; The Iowa University Press: Ames, IA, USA, 1967; pp. 286-306.

28. Buxton, A.; Fraser, G. Animal Microbiology; Blackwell Scientific Publications: London, UK, 1977; Volume 1, pp. 400-480.

29. Office International Des Epizooties (OIE). OIE Manual Part-2: Pullorum Disease and Fowl Typhoid in: OIE Manual Diagnostic Tests and Vaccines for Terrestrial Animals; OIE: Paris, France, 2004.

30. Bauer, A.W.; Kirby, W.M.M.; Sherris, J.C.; Turck, M. Antibiotic sensitivity testing by a standardized single disk method. Am. J. Clin. Pathol. 1966, 45, 493-496. [CrossRef]

31. Clinical and Laboratory Standards Institute (CLSI). Performance Standards for Antimicrobial Disk Susceptibility Tests, Approved Standard M2-A8; CLSI: Wayne, PA, USA, 2006.

32. Cappuccino, J.C.; Sherman, N. Microbiology, A Laboratory Manual; Pearson/Benjamin Cummings: San Francisco, CA, USA, 2005; pp. 125-179.

33. Riffon, R.; Sayasith, K.; Khalil, H.; Dubreuil, P.; Drolet, M.; Lagace, J. Development of a Rapid and Sensitive Test for Identification of Major Pathogens in Bovine Mastitis by PCR. J. Clin. Microbiol. 2001, 39, 2584-2589. [CrossRef] [PubMed]

34. Saitou, N.; Nei, M. The neighbor-joining method: A new method for reconstructing phylogenetic trees. Mol. Biol. Evol. 1987, 4, 406-425.

35. Kumar, S.; Stecher, G.; Tamura, K. MEGA7: Molecular Evolutionary Genetics Analysis version 7.0 for bigger datasets. Mol. Biol. Evol. 2016, 33, 1870-1874. [CrossRef]

36. Tamura, K.; Nei, M.; Kumar, S. Prospects for inferring very large phylogenies by using the neighbor-joining method. Proc. Natl. Acad. Sci. USA 2004, 101, 11030-11035. [CrossRef]

37. Souto, L.I.; Minagawa, C.Y.; Telles, E.O.; Garbuglio, M.A.; Amaku, M. Correlation between mastitis occurrence and the count of microorganisms in bulk raw milk of bovine dairy herds in four selective culture media. J. Dairy Rese 2010, 77, 63-70. [CrossRef]

38. Bachaya, H.A.; Raza, M.A.; Murtaza, S.; Akbar, I.U.R. Subclinical bovine mastitis in MuzaffarGarh district of Punjab (Pakistan). J. Anim. Plant. Sci. 2011, 21, 16-19.

39. Anjali, G.; Kashyap, S.K. Identifcation of Bovine Mastitis Associated Pathogens by Multiplex PCR. Dairy Vet. Sci. J. 2017, 3. [CrossRef]

40. Gundogan, N.; Avci, E. Occurrence and antibiotic resistance of Escherichia coli, Staphylococcus aureus and Bacillus cereus in raw milk and dairy products in Turkey. Int. J. Dairy Technol. 2014, 67, 562-569. [CrossRef]

41. Begum, H.A.; Uddin, M.S.; Islam, M.J.; Nazir, K.H.M.N.H.; Islam, M.A.; Islam, M.T. Detection of biofilm producing coagulase positive Staphylococcus aureus from bovine mastitis, their pigment production, hemolytic activity and antibiotic sensitivity pattern. J. Bangladesh Soc. Agric. Sci. Technol. 2007, 4, 97-100.

42. Shitandi, A.; Sternesjo, A. Prevalence of Multidrug Resistant Staphylococcus aureus in Milk from Largeand Small-Scale Producers in Kenya. J. Dairy Sci. 2004, 87, 4145-4149. [CrossRef] 
43. Gundogan, N.; Citak, S.; Turan, E. Slime production, DNAse activity and antibiotic resistance of Staphylococcus aureus isolated from raw milk, pasteurised milk and ice cream samples. Food Control 2006, 17, 389-392. [CrossRef]

44. Zafolon, L.F.; Langoni, H.; Benvenutto, F.; Castelani, L.; Broccolo, C.R. Aspectos epidemiológicos da mastite causada por Staphylococcus aureus. Veterinária Zootec. 2008, 15, 56-65.

45. Gundogan, N.; Citak, S.; Yalcin, E. Virulence properties of extended spectrum $b$-Lactamase-producing Klebsiella species in meat samples. J. Food Prot. 2011, 74, 559-564. [CrossRef]

46. De Oliveira, A.P.; Watts, J.L.; Salmon, S.A.; Aarestrup, F.M. Antimicrobial susceptibility of Staphylococcus aureus isolated from bovine mastitis in Europe and the United States. J. Dairy Sci. 2000, 83, 855-862. [CrossRef]

47. Guerin, F.V.; Carret, G.; Houffstchmitt, P. In vitro activity of 10 antimicrobials agents against bacteria isolated from cows with clinical mastitis. Vet. Rec. 2003, 152, 466-471. [CrossRef]

48. Noskin, G.A.; Rubin, R.J.; Schentag, J.J.; Kluytmans, J.; Hedblom, E.C.; Smulders, M. The burden of Staphylococcus aureus infections on hospitals in the United States: An analysis of the 2000 and 2001 Nationwide Inpatient Sample Database. Arch. Intern. Med. 2005, 165, 1756-1761. [CrossRef]

49. Huijsdens, X.W.; Van Dijke, B.J.; Spalburg, E.; Van Santen-Verheuvel, M.G.; Heck, M.E.O.C.; Pluister, G.N.; Voss, A.; Wannet, W.J.B.; De Neeling, A.J. Community-acquired MRSA and pig-farming. Ann. Clin. Microbiol. Antimicrob. 2006, 5, 26. [CrossRef] [PubMed]

50. Köck, R.; Ballhausen, B.; Bischoff, M.; Cuny, C.; Eckmanns, T.; Fetsch, A.; Harmsen, D.; Goerge, T.; Oberheitmann, B.; Schwarz, S.; et al. The impact of zoonotic MRSA colonization and infection in Germany. Berl. und Munchener tierarztliche Wochenschr. 2015, 127, 384-398.

51. Pantosti, A. Methicillin-Resistant Staphylococcus aureus Associated with Animals and Its Relevance to Human Health. Front. Microbiol. 2012, 3, 1-12. [CrossRef] [PubMed]

52. Dweba, C.C.; Zishiri, O.T.; El Zowalaty, M.E. Methicillin-resistant Staphylococcus aureus: Livestock-associated, antimicrobial, and heavy metal resistance. Infect. Drug Resist. 2018, 11, 2497-2509. [CrossRef]

(C) 2020 by the authors. Licensee MDPI, Basel, Switzerland. This article is an open access article distributed under the terms and conditions of the Creative Commons Attribution (CC BY) license (http://creativecommons.org/licenses/by/4.0/). 